\title{
SOME OBSERVATIONS ON THE THEONOE MOSAIC FROM ZEUGMA
}

\author{
Kutalmış GÖRKAY, Pascale LINANT DE BELLEFONDS, Évelyne PRIOUX*
}

\author{
Anahtar Kelimeler: Zeugma $\bullet$ Theonoe $\bullet$ Leukippe $\bullet$ Mozaik $\bullet$ Pantomime $\bullet$ Mozaik yazitları \\ Keywords: Zeugma $\bullet$ Theonoe $\bullet$ Leukippe $・$ Mosaic $・$ Pantomime $\bullet$ Mosaic inscriptions
}

\begin{abstract}
Özet:
Bu makale Zeugma'da bulunmuş Theonoe olarak bilinen mozaiğin üzerinde daha önce fark edilmemiş bir yazıtla birlikte, mozaikte yeralan diğer bir yazıtın epigrafik değerlendirmesi, sahnenin mitolojik yeni yorumu ve mimari bağlamı ile ilişkisini ele almaktadır. Bu yazıtlardan ilki mozaiğin sol

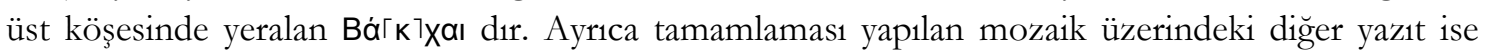

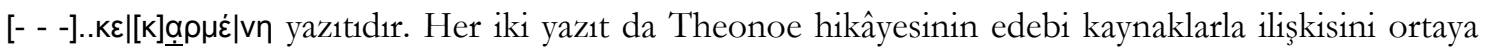
koymaktadır. Mozaik üzerindeki karakterlerin ikonografisi, yazıtlar ve edebi metinler ile birlikte değerlendirildiğinde, Theonoe mozaiğindeki konunun mim şeklinde oynanan kayıp bir tiyatro oyunu ile ilişkili olabileceği ortaya çıkmaktadır.
\end{abstract}

\begin{abstract}
:
This paper presents a new discovery on the Theonoe Mosaic from Zeugma and reassesses its evaluation in mythical and architectural context. This discovery pertains to two inscriptions found

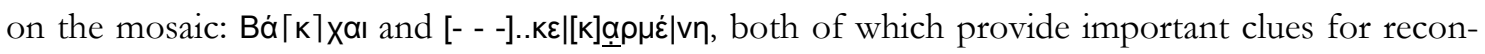
structing the myth of Theonoe and the image's possible connection to literary sources. The characters' iconography, when studied closely and analyzed in light of the remaining inscriptions, speaks for a possible relationship between the Theonoe mosaic and a lost theatrical performance, possibly a mime.
\end{abstract}

\footnotetext{
We would like to thank J. Balty, I. David, M.-R. Falivene, K. Gutzwiller, T. Özhan, A. Piqueux and B. Yıldırım for their helpful comments on earlier drafts of this paper. All mistakes remain our own. For epigraphical conventions, we have followed Panciera 1991.
} 
The Theonoe mosaic was found in 2002, in the triclinium of a Roman house in Zeugma. The other mosaic found in the triclinium represents Achilles at Skyros. The scene depicting Theonoe decorates the central square emblema of the mosaic that was placed between the klinai ${ }^{1}$. The dimensions of the mosaic are $2.50 \times 2.40 \mathrm{~m}$. The mosaic itself is inscribed with the artist's signature

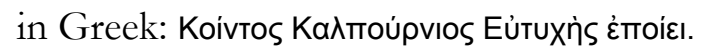

According to the inscription, the mosaist was called Quintus Calpurnius Eutykhes (Fig. 1). The original plan of the triclinium was changed in the $4^{\text {th }}$ and $5^{\text {th }}$ centuries $\mathrm{AD}$ by the adjunction of a little fountain and separator walls ${ }^{2}$.

On the scene at the left are two draped female figures. The one on the left wears a yellowish bimation over her chiton, whereas the chiton is the only visible garment of the other character. Both females have imposing hairdos and ornaments consisting of flowers or leaves in their hair. Both wear elaborate earrings. Certain spots on the mosaic's surface bear severe burn traces. On the burned area that extends above these two female figures, are six letters, that one can only difficultly read: BAX XAI. The inscription identifies these two draped female figures as Bá $\lceil\kappa\rceil\left(\right.$ uac.)xaı (Bákхaı) ${ }^{3}$ (Fig. 2). The khi has been mistaken for a kappa, perhaps as a result of a copy from a manuscript written in uncials; it should be noted, though, that this mistake is not infrequent, as appears from a short enquiry in the SEG indi-

Önal 2008, 265, fig.2, 266, fig. 3.

2 Önal 2008, 271-272. About the problems that are raised by such "signatures", see infra n. 29.

3 Önal has carefully noticed the last three letters of the inscription. See Önal 2008, 268. $\operatorname{ces}^{4}$. As for the uacat that stands in the middle of the word, it is not unusual in mosaics $^{5}$.

In the centre of the scene, are two female figures. Two well-preserved inscriptions identify the woman in the centre as Theonoe (Orovón), and the older woman next to her as a "nanny" (трофós). With her elegant costume and her rich ornaments, Theonoe appears to be the most prominent character in the overall composition as we know it. She wears, over a reddish longsleeved, full-length tunic, adorned with stripes towards the hem, a fringed sash or stole crossing her chest and hips diagonally and hanging down from her left shoulder. This dark colored sash or stole is embroidered with a greenish foliage scroll pattern. Theonoe has slightly wavy hair, parted in the middle and drawn into a small knot on the top of the head, and hanging down in exceptionally long and straight locks down the side of the face and onto the shoulders. Her face is remarkable, with its sharply defined oval, its pale complexion contrasting with the darker colored neck, its large black eyes and its small closed mouth.

The figure at the right is probably Leukippe, Theonoe's sister, dressed up as a priest in a white long-sleeved tunic and a white bimation, both trimmed with vertical black stripes or clavi. She wears yellow shoes enclosing the entire foot and even the ankle and tied with a lace above the instep. The sole is thick and follows the outline of the foot, with a slight indentation between the first and second toes. The

\footnotetext{
4 For the name Bákxn inscribed on monuments, see LIMC III, s.v. "Bakche", 80 (A. Kossatz-Deissmann).

5 See for example Nei kè for Nike on another mosaic from Zeugma: Önal 2003, 18-19.
} 
upper body and the head of Leukippe are missing, probably looted. It should be noted, though, that Leukippe's left shoulder, part of her neck and left cheek, and what should probably be interpreted as a darkblue veil were to be seen on one of the mosaic's fragments as found in situ and before the scene's restoration (Fig. 3).

A round altar standing on a square base can be seen between Theonoe and Leukippe. The artist's signature is preserved in a tabula on the square base of the altar. In the left hand, the priest holds a laurel branch with a stemma hanging from it. This may well be a specific object used during the offering to Apollo $^{6}$, for whose cult Leukippe cut her hair and dressed as a male priest. In her right hand, she holds what looks like a rose bud. Nevertheless, it is not clear whether she is depositing the flower as an offering on the altar or if she is picking it, in which case someone else, maybe Theonoe, would have placed it on the altar, possibly as a love gift meant for the young priest she fell in love with.

On another mosaic fragment originally set in the upper right corner of this composition, one can still read the remains of eight, possibly nine, letters of an inscription probably related to Leukippe, the crossdressed character: two vertical hastae are followed by the letters KE[- - -?]PMENH (Fig. 1). A photograph taken during the excavation shows that the right part of a triangular letter, that one can safely assume to be an al-

6 The laurel is traditionally linked with Apollo. As for stemmata they are often used as a distinctive mark of people or cult instruments in the apollinian sphere: see ThesCRA V.2.b, 397. For instance, on an Apulian volute crater by the Darius Painter (Geneva, Art and History Museum 24692) Cassandra holds a laurel branch with a stemma: Aellen, Cambitoglou, Chamay 1986, fig. 72. pha, was to be read in the lacuna just before the rho (Fig. 3). As we shall see, a tentative reconstruction of this inscription can only be proposed once the entire scene has been studied. This inscription thus requires further elucidation.

The scene represented on this mosaic is exceptional and is so far unparalleled. It is most probably related to the story of Theonoe and Leukippe, a myth only reported by Hyginus in his Fabulae 190. However the situation shown on the mosaic does not match accurately the literary source, since neither Bacchants nor trophos were mentioned by Hyginus.

The elegantly ornamented drapery perhaps reveals that Theonoe enjoyed a privileged aristocratic status or may indicate her royal rank since she became a prominent mistress of King Icarus ${ }^{7}$. The trophos represented between both sisters also emphasizes Theonoe's status. One puzzling detail is the embroidered stole crossing Theonoe's breast. This is clearly a characteristic element of the Isiac costume, worn by the goddess herself, by her priestesses or by her worshippers. This element, which looks very much like the palla described by Apuleius (met. 11, 3-4), can be seen on very few monuments, all of which are related to an Isiac context ${ }^{8}$. In this respect it is quite appealing to associate the way Theonoe is represented on this mosaic with the other Theonoe, the daughter of the Egyptian King Proteus, who, as a prophetess, plays a major role in Euripides' Helen. One may wonder whether this scene involved a certain confusion between both characters

\footnotetext{
Hyginus $(190,7)$ calls her reginam.

8 See for instance a mosaic from Antioch dated in the Severan period. Levi 1947, 49-50, pl. VIIIb.
} 
or if the mosaist picked up the figure of Theonoe, the Egyptian priestess, in some practical patternbook. Another possible explanation would be that a literary source involving Leukippe and Theonoe suggested an Egyptian background for the characters or for part of the story, as is often the case in novels?.

As for the Bacchants, the context of the mosaic, a triclinium, may account for their presence in the scene, although such characters could also be reminiscent of the chorus of some lost play on Leukippe and her sister, or allude, alternatively, to a specific cultural context attested in Theonoe's story (the scene may for example have been thought to take place during a bacchic festival). In any case one should emphasize that the Bacchants are here featured in a hieratic pose which they usually do not have ${ }^{10}$.

It is now worth asking whether this mosaic should be analyzed as the reflection of a dramatic performance, such as a mime or a pantomime - two genres that enjoyed great success in Imperial times. Even if the scene has no overt signs pointing to the stage, such as an architectural backdrop or curtains, one cannot help notice certain details that may induce us to relate this image to a lost play or perhaps to an undocumented novel. Before going any further, the authors of this paper would like to emphasize that they do not consider this

9 The rose-bud on the altar is another possible feature pointing to the Isiac cult, in which the abundance of flowers - especially roses - is characteristic.

10 Suffice it to say that another mosaic from Zeugma depicts Dionysos with Nike and a female follower identified by the inscription as Bákxn (see above, n. 6): in this case, the Maenad is dancing in a swirling movement and playing cymbals. mosaic as the very reproduction in the visual arts of a scene that was once seen on a stage: it is certainly very different from the Synaristosae mosaic found in the same city. And yet, we would like to call the reader's attention on the various details that could have been reminiscent of a theatrical performance: one of these is Theonoe's masklike facies, another is the presence of the Bacchants - a possible reminiscence of a chorus - and a third element would be the fragmentary inscription on the right that might point, as we shall see, to the title of a lost play. Some of the visual elements may seem to indicate a reference to a lost mime, whereas others (Theonoe's "mask") rather point to pantomime. It would thus be erroneous to present this mosaic as unmistakably reminiscent of a specific literary genre; the authors of this paper rather think that the mosaic was intended to suggest a literary and drama-related background through various details, without necessarily alluding to a specific show. We would also like to stress that much remains to be discovered about the popular forms of theater that existed in the imperial era, especially in Orient ${ }^{11}$, and that the connections that we may propose between the Theonoe mosaic and paraliterary/subliterary genres are therefore bound to remain speculative.

All five figures are conspicuously arranged facing the viewer and are placed in front of a light background, with depth suggested only by some overlapping and the shadows at their feet. Among the figures, Theonoe and Leukippe appear to be the nearest to the viewer whereas the "nanny" and one of the Bacchants are the farthest away from

11 See for instance Pack 1993, 749-754. 
him, as if to suggest a positioning that might occur in a performance. The presence of three main characters (Theonoe, Leukippe, the "nanny") plus a possible chorus (the Bacchants) could well be reminiscent of a Greek mime ${ }^{12}$.

Let us now take a closer look at Theonoe herself. Her style is certainly theatrical: her figure is imposing, and her elaborate longsleeved, full-length dress, made of expensive material, resembles that worn by an actor ${ }^{13}$. Moreover, her oval face, pale complexion and aforementioned hairdo do evoke, if not a genuine mask, at least some features known from theatre masks ${ }^{14}$. If so, her closed mouth could possibly point to a pantomime mask ${ }^{15}$. On the contrary, mask

12 See Wiemken 1972, 174-179. The Greek mimes of the imperial period that have been preserved all feature a female character as their first actor (character A). Wiemken provides a list of imperial mimes including a chorus.

13 On the expensive and colourful dresses worn by mime actresses in Orient see the references provided by Wiemken 1972, 204.

14 Theonoe's hairdo, with its strands parted in the middle, bears similarities to the kore's mask of New Comedy: cf. mask $\mathrm{n}^{\circ} 33$ in Pollux' catalogue (Onomasticon, IV, 143154) and Webster 1995, 41.

15 The pantomime masks differ from the masks of drama in that they have a closed mouth; hence the difficulty, when the theatrical context is not certain, of distinguishing between masks with closed mouth which belong to pantomime and faces with similar features: see Jory 2001 and Jory 2002 (who insists, p. 253, on the "burgeoning of pantomime iconography" throughout the Greek East at the end of the second century). Concerning the difficulty in distinguishing masks and faces in the context of mosaic, it is worth mentioning a few comments about the mosaic from Zeugma depicting three seated women identified by an inscription as Menander's Synaristosai. Abadie-Reynal - Darmon 2003, 97: "Le visage de la vieille, à la mimique grimaçante et aux traits marqués, évoque sans ambiguité un masque de comédie. Il est plus difficile de décider si les autres personnages sont censés porter un masque de théatre. On peut cependant remarquer que les deux visages des jeunes femmes, de forme arrondie, ont une expression quasiment identique, avec même traitement de la bouche, du nez et des yeux, et peuvent avoir représenté un même type de masque would not be expected if the mosaic were to present a lost mime - an hypothesis that should, as we shall see, also be taken into account. Moreover, one should note that pantomimes were centered on soloperformances, a feature that does not match with the presence, within the scene, of two other prominent characters: Leukippe and the trophos, who does not share Theonoe's masklike facies.

And yet, even if the trophos is not featured here with her usual wrinkled face that looks like a theatre mask $^{16}$, the nanny-character is possibly reminiscent of a theatre play or a novel (of course, such characters also appear in epyllia). She thus participates in turning the mythological scene into a theatre scene $\mathrm{e}^{17}$.

The setting of the mosaic in a triclinium is significant too since recitations sometimes took place in private houses as banquet entertainments $^{18}$. In this respect, the two Bacchai who witness the scene may also be read, as we already noted, as indicators of theatricality. Acting like the dramatic chorus, as an intermediary between the reality of the dining-room and the mythological world depicted on the mosaic, they entice the viewer to participate in the significant event that takes place in the center of the scene.

caractérisant des personnages de types voisins. La délimitation marquée du menton, nettement isolé du cou, peut aussi confirmer l'bypothèse du port d'un masque par les deux jeunes femmes." And Seeberg 2002-2003, 45: "The young women wear long actors' sleeves that are just visible, but characters have faces rather than recognizable masks."

16 See for instance Pasiphae's nurse on a mosaic in Zeugma: Darmon 2005, fig. 14b ; Ergeç 2007, 100-103.

17 Concerning the nurse as a theatrical character, see the comments of M.-H. Quet apud Darmon 2005, 1299, who thinks that the Pasiphae's mosaic from Zeugma refers implicitly to a pantomime scene.

18 Dunbabin 1996, 66-67 and 78-79. 
If we now consider the inscriptions, one of the most tantalizing issues would be the reconstruction and interpretation of the fragmentary word(s) inscribed on the right side of the mosaic, on a broken fragment that originally completed the area behind Leukippe's left shoulder and veil (?). ${ }^{19}$ During the restoration that preceded the display of this mosaic in the Gaziantep Museum, this fragment was positioned a little too high. However, since the contour of Leukippe's shoulder could be seen in the lower left corner of the fragment (Figs. 1, 3, 4), it was repositioned in the image at the apposite height.

As we already noted, two vertical hastae, corresponding to the remains of one or two lost letters, precede the surviving letters: $\kappa \varepsilon|[. ?] \underline{\alpha} \rho \mu \dot{\varepsilon}| v \eta$. The letters vn are framed with two symbols: a curved slash-shaped stroke on the left and a hedera on the right. These two symbol may be part of an effort to center harmoniously the inscription within a given space. The slash-shaped stroke strongly suggest that one or two letters were lost left of the $\varrho$ in the previous line and left of the two fragmentary vertical hastae in the first line. This leaves us with the following

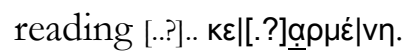

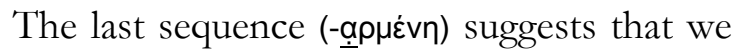
should read the word as a perfect participle in the mediopassive voice. The surviving $к \varepsilon$ suggests that the lost stem of this participle started with $к$ or $\mathrm{x}$. Supposing that two letters were lost before the $-\rho \mu \dot{\varepsilon} \mid \mathrm{vn}$ sequence, we are left, as it seems, with two possibili-

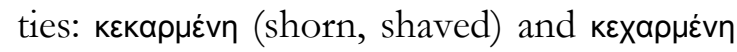

\footnotetext{
19 On the left edge of this fragment, some of the tesserae designed to represent the curved contour of Leukippe's shoulder are still visible.
}

(joyful, delighted). The first reading would be in keeping with the myth told by Hyginus, since Leukippe cut her hair (capillos totondit) after hearing Apollo's oracle. On reading this inscription, the viewer would have been provided with enough clues to understand why Apollo's priest looked like a man, but was in fact a woman; his attention would also have been drawn on the cross-dressing, an element that justifies, as we shall see, the juxtaposition of two myths within the same pavement.

The two vertical hastae could correspond to the traces of two separate letters. If so, we could suggest the following reading:

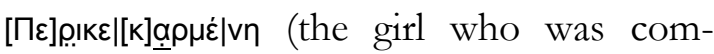
pletely shorn). This reading could be a mere didascaly meant to help the viewer understand the scene by qualifying the crossdressed Leukippe and explaining why she looked like a male (supposing that a veil was covering her head - which would not be surprising for a priest -, the inscription would also have been meant to confirm or signal to the viewer that she was shorn), but it may also be read as a title, maybe the title of a lost mime illustrated in this scene (it should be noted though, that the titles the plays illustrated in other mosaic are not inscribed on the right edge of the image) ${ }^{20}$. If our inscription was to be interpreted as a dramatic title, the word would be reminiscent of the title of Menander's Perikeiromene (the difference between perfect and present tense may perhaps be accounted for in the following manner: whereas Menander's Glykera was possibly shorn during the play

20 Participles are very common among titles of ancient mimes, as they are for comedy. We know famous examples from Sophron and further examples are provided, for instance, by the titles of Herodas' Mimiambi 4, 6, 9 and 11. 
- in the lost first scene? -, Leukippe would have been shorn before the play started, which would be in keeping with a scene taking place in Caria).

A lost $\eta$ could also fit our traces. If so, we may suggest the following readings:

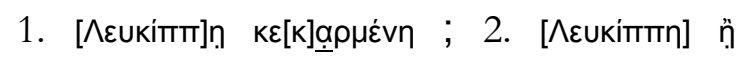

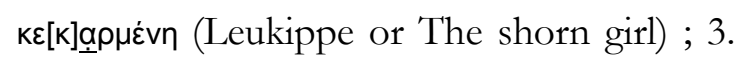

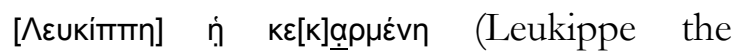
shorn $)^{21}$. Although such possibilities may at first sound interesting, it seems to us that arguments pertaining to the arranging of the letters and general design of the inscriptions within the image tend to encourage the

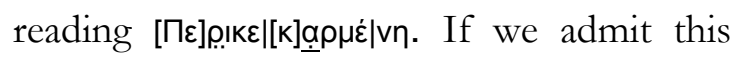
reconstruction, the reason for which the mosaist inserted two symbols (a curvy stroke and the hedera) in the third line immediately appears: his point was to present the inscription within a square and to give it a block-like shape (Fig. 4). A further detail that went unnoticed during the restoration was that a few black tessellae were to be found beneath this inscription, right under the middle of the three lines. The shape of this lost mark suggests that it was a curvy stroke similar to the one found after the Bakkhai inscription. If one reconstructs the shape of Leukippe's lost head and veil (?), enough space is left to insert a further inscription above her head, at the same level

\footnotetext{
21 The last two suggestions bring us back to possible titles for lost dramatic productions. Lenkippe or The shorn gir would evidently correspond to alternate titles for the same play. And yet, this reading may seem difficult to sustain, since alternate titles are rather known as a scholarly device that may seem a little out of place in a mosaic. The other possibility, Leukippe the shorn, would resemble titles like Euripides' Melanippe the Wise

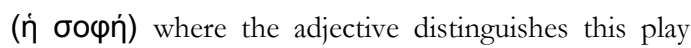
from the poet's other Melanippe.
}

as the Erovón inscription. It is thus tempting

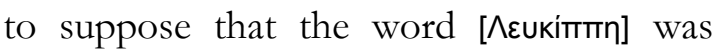
written in the lost corner of the mosaic. If one aligns the end of this word with the

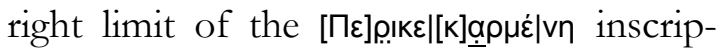
tion, the name would have started just above the crown of her head as was the case for her sister Theonoe. If one then supposes that a separating symbol such as a curvy stroke or a hedera was to be found above the $[\Pi \varepsilon] \rho \underline{\rho}|\kappa \varepsilon|[\kappa]$ a $\rho \mu \varepsilon \dot{\varepsilon} \mid v \eta$ inscription, symmetrically to the curvy stroke inscribed under the word, this further mark would have stood in the very middle of the space available between the character's name ([^⿻икіттп]) and the participle

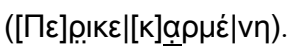

As we saw, the fragmentary inscription behind Leukippe's shoulder may, as a participle, be reminiscent of the title of a lost dramatic production. Could we be more precise about the image's possible connection to a literary genre? Of course, the novel-like pattern and structure of Leukippe's story may suggest a lost mime (connections between mimes and novels have indeed been stressed for cases such as Metiochus and Parthenope or Hero and Leander $^{22}$ ). In Leukippe's case, a tantalizing parallel is provided by a $5^{\text {th }} / 6^{\text {th }}$ cent. papyrus: $P$. Berol. $13927=$ Pack $^{2} 2437=\mathrm{SB}$ $26.16648^{23}$. The fragments of this papyrus

22 Hanfmann 1939, pp. 245-246; Quet 1992, 135-140; Mignona 1996a, passim and esp. 233 n. 5 (with further bibliography); Mignogna 1996b, 163. It is worth emphasizing that one of the mosaics depicting Metiochus and Parthenope comes from Zeugma: Önal 2003, 5455 .

23 Manteuffel 1929; Cazzaniga 1958; Wiemken 1972, 191 197; Cunningham 1987, 60-61 and appendix 15; Mignogna 1996a and 1996b; Rupprecht-Hengstl 2006 (= SB 26, n 16648). 
pertain to a lost mime (col. Ib) and to shorter entertainments - «paignia» (col. Ia and II). The first column contains the title of a lost mime (Лвикіптп) and then a list of the various stage props and accessories that its staging required (1. 10-21): the papyrus mentions a scene at the barber's shop involving rasors, a mirror and other accessories such as a blacksmith's tools, a little statue or portrait, three loafs of bread (?), and a garment made of linen. Four characters were apparently involved: Leukippe, the barber, an old woman and a blacksmith $^{24}$. On publishing these lines, G. Manteuffel reasonably thought that they had nothing to do with the mythical Leukippe, but that they derived of a novel, possibly Achilles Tatius' Leukippe and Clitophon. Cazzaniga and Cunningham were, on the contrary, reluctant to draw a close parallel between the papyrus and Achilles Tatius' novel, since the Leukippe known from the novel does not explicitly visit a barber shop. More recently, Mignogna has brought attention on the fact that Achilles Tatius' Leukippe was in fact shorn when taken by the pirates (5.17.3 and 5.19) and turned into a slave wearing chains. She suggested that the lost mime may have been loosely inspired by the novel and centered on Leukippe's transformation into a slave: according to Mignogna, the barber's function would have been to shave Leukippe's hair and the blacksmith's to forge her chains, whereas the eikonion may have been a portrait of Clitophon to whom Leukippe addressed her complaints. This may of course be right; and yet, the new Zeugma mosaic now drives our attention to the cross-dressing of the mythological

24 See Wiemken 1972, 196; Mignogna 1996b.
Leukippe and shows that a lost mime or theatrical performance of some sort may have given a specific importance to her shorn hair. If one considers this new evidence, it is less clear that the Berlin papyrus deals with a parallel story concerning Achilles Tatius' Leukippe and not the mythical Leukippe. Supposing that the fragmentary stage indications provided by P. Berol. 13927 did in fact pertain to a lost play dealing with the mythical Leukippe, we would have possible evidence for two separate mimes derived from the same story: the papyrus would concern the first whereabouts of Leukippe and her dressing as a priest (Leukippe's cross dressing could thus account for the barber tools and for the linen garment attested in the papyrus, but the blacksmith's tools would remain problematic), whereas the mosaic would possibly illustrate a play in which Leukippe had already been shorn ((Peri)kekarmene) and arrived in Caria.

As we have noted above, the mosaic depicting Theonoe and Leukippe was found in a triclinium. The other mosaic in the same triclinium depicts Achilles hiding in the island of Skyros ${ }^{25}$, a favourite theme for mosaics found in domestic settings ${ }^{26}$. Both scenes are connected with each other in their mythological context. Theonoe and Leukippe belong to a family of seers including such a prominent figure as Calchas $^{27}$, who prophesied that the Achaeans would not win the Trojan War without the presence of Achilles. This prophecy was the reason for which Odysseus set out to find Achilles who was

\footnotetext{
25 Önal 2008, 263-273.

26 Muth 1998, 151ff.

27 RE 2,V2 2088-2089; Roscher 1916-24, 631, s.v. "Theonoë" (2) .
} 
hiding in Skyros dressed up in female garments. As a matter of fact, Achilles' cross-dressing provides us with a further connection between both myths. Both stories are indeed linked on a thematic level thanks to this very motive: whereas Achilles dresses up as a girl, Leukippe dresses up as a man.

Furthermore, the story of Achilles' concealment as a woman seems to have been a favourite topic in ancient pantomimes (see Lucianus, salt. 46 and Choricius of Gaza, Orationes 32). In a similar vein, one can imagine the dramatic potential of crossdressing in Leukippe's story.

As we mentioned earlier, the basis of the round altar bears the artist's signature in Greek. According to the inscription, the mosaist was called Quintus Calpurnius Eutykhes $^{28}$. His gentilicium and his cognomen are both very common. We have no hard evidence allowing us to connect this mosaist to the Eutykhes son of Barnabion whose signature was found on a mosaic in ElMas'oudiye $(\text { Syria })^{29}$. Both mosaics seem to be different in style and it should be noted that Eutykhes is a very common name in Syria. Besides, one can hardly account for the difference between both signatures: why would this mosaist give his patronyme in ElMas'oudiye, and rather indicate his tria nomina in Zeugma?

\footnotetext{
28 Önal 2008, 265. See infra n. 29.

29 Parlasca 1989, 263-267. Balty 2004 suggests a new interpretation of the inscription found in El-Mas'oudiye: as in several other examples, the name that was inscribed on the pavement may not refer to the artist, but to the man who commissioned the mosaic. According to J. Balty (personal communication), the same precaution should perhaps be taken with the Theonoe mosaic: if so, the verb "epoiei" would not mean "has done (this)" but "had (this) done".
}

To conclude this presentation, we would like to insist on the dramatic and novel-like elements of Leukippe's story and to propose a possible connection with a mime or possibly a pantomime performance. It is known that this kind of theatrical productions were one of the key-elements in the transmission and diffusion of literary and mythological plots in the Imperial period ${ }^{30}$. With its novel-like and dramatic features ${ }^{31}$, the story of Theonoe and Leukippe was likely to have inspired such performances and may have been especially appreciated in an Anatolian context because of its Carian setting. If not clearly linked to an identifiable dramatic production or literary genre, the mosaic certainly shows traces of an interest in the kind of aesthetic experience that may have been conveyed by mythrelated pantomimes. Of course, the "onstage" characters would be too numerous (the point of a pantomime was the soloperformance), but the two Bacchants may indicate an allusion to a chorus and Theonoe's face, with its pale oval, its hairdo and its closed mouth does bear some resemblance to pantomime masks. On a mosaic found in Elis and representing Polymnia as the muse of pantomime $e^{32}$, the goddess wears a mask that shares certain peculiarities with Theonoe's would-be mask: they have the same expression and the upper part of both character's hairdo is similar, even if some differences occur in the long strands of hair on each side of their

\footnotetext{
30 Garelli 2006.

31 See, for instance, the aforementioned allusions to the Isiac cult and to elements of Egyptian "exotism", but also the pirates or Leukippe's shorn hair - ingredients that both featured in Achilles Tatius' Leukippe and Clitophon (see $₫ 5.17 .3$ and 5.19 for Leukippe's shorn hair).

32 Waywell 1979, spec. cat. n²5, 298-299 and pl. 48, fig. 23.
} 
heads $^{33}$. Supposing that the Theonoe mosaic was indeed alluding to a mime or pantomime scene, the triclinium would have been adorned with two scenes loosely related to popular forms of drama - two mythologic examples of cross-dressing, that were likely to remind their viewers of myth-related entertainments. Of course, these images cannot be understood as accurate illustrations of pantomime scenes (such scenes would indeed have been centered on the movement of the actor's body and hands), but they possibly reflect an interest in this influential genre and in the myths it conveyed.

The acuteness shown in the selection and combination of both scenes certainly demonstrates the patron's belonging to an intellectual elite as well as his taste for theatrical entertainment. One would readily imagine that such performances may have been organized as dinner shows in the triclinium.
Assoc. Professor Kutalmış Görkay

Ankara Üniversitesi

Dil ve Tarih-Coğrafya Fakültesi

Arkeoloji Bölümü

06100 Sihhiye / Ankara

e-mail: kgorkay@yahoo.com

Dr. Pascale Linant de Bellefonds

Research Director

CNRS, Paris X-Nanterre, UMR 7041 ArScAn équipe LIMC

Maison de l'Archéologie et de l'Ethnologie René Ginouvès

21 allée de l'Université

F-92023 Nanterre Cedex

e-mail: pascale.linant-de-bellefonds@mae.u-paris10.fr

Dr. Évelyne Prioux

Scientific researcher

(CNRS, Paris X-Nanterre, UMR 7041 ArScAn équipe ESPRI), boîte 9, Maison de l'Archéologie et de l'Ethnologie - René Ginouvès

21, allée de l'Université

F - 92023 Nanterre CEDEX

e-mail: evelyne.prioux@mae.u-paris10.fr

33 Further examples of pantomime mask are provided by the findings of the Athenian agora: see Grandjouan 1961, cat. 508 and esp. 516. 


\section{List of Figures:}

Figure 1. The Theonoe Mosaic as exhibited in the Gaziantep Museum. (K. Görkay).

Figure 2. Detail of the Bacchai inscription on the Theonoe Mosaic... (K. Görkay).

Figure 3. Inscribed fragment at the time of its discovery. (M. Sait Yllmaz).

Figure 4. Tentative epigraphical and archaeological reconstruction of the mosaic: all restitutions are in light grey (É. Prioux, K. Görkay). 


\section{BIBLIOGRAPHY}

Abadie-Reynal -

Darmon 2003

Aellen - Cambitoglou - Chamay 1986

Balty 2004

Cazzaniga 1958

Cunningham 1987

Darmon 2005

Dunbabin 1996

Garelli 2006

Grandjouan 1961

Hanfmann 1939

Jory 2001

Jory 2002

Levi 1947

Manteuffel 1929

Mignogna 1996a

Mignogna 1996b

Muth 1998

Önal 2003

Önal 2006

Önal 2008

Pack 1993
C. Abadie-Reynal - J.-P. Darmon, "La maison et la mosaïque des Synaristôsai (Les Femmes au déjeuner de Ménandre)", in: Zeugma: Interim Reports, JRA suppl. 51 (2003) 95-99.

Ch. Aellen - A. Cambitoglou - J. Chamay, Le peintre de Darius et son milieu (1986).

J. Balty, "Artiste ou commanditaire? La mosaïque de Mas'udiye", in: M. Fano Santi (ed.), Studi di archeologia in onore di Gustavo Traversari (2004) 11-15.

I. Cazzaniga, "Note marginali al papiro berlinese 13927 (V-VI sec. d. C.): un inventario di oggetti necessari per rappresentazioni sceniche", Studi Classici e Orientali 7, 1958, 7-19.

I. C. Cunningham, Herodae Mimiambi, cum appendice fragmentorum mimorum papyraceorum (1987).

J.-P. Darmon, "Le programme idéologique du décor en mosaïque de la maison de la Télétè dionysiaque, dite aussi de Poséidon à Zeugma (Belkis, Turquie)", in: H. Morlier (ed), La Mosaïque gréco-romaine IX (2005) 1279-1300.

K. M. D. Dunbabin, "Convivial spaces: dining and entertainment in the Roman Villa", JRA 9, 1996, 66-80.

M.-H. Garelli, "Pantomime, tragédie et patrimoine littéraire”, Pallas 71, 2006, 113 125.

C. Grandjouan, The Athenian Agora VI, Terracottas and Plastic Lamps of the Roman Period, (1961).

G. M. A. Hanfmann, "Notes on the Mosaic from Antioch", AJA 43, 1939, 229246.

J. Jory, "Some cases of mistaken identity? Pantomime masks and their context", BICS 45, 2001, 1-20.

J. Jory, "The masks on the propylon of the Sebasteion at Aphrodisias", in: P. Easterling and E. Hall (eds.), Greek and Roman actors (2002) 238-253.

D. Levi, Antioch Mosaic Pavements (1947).

G. Manteuffel, “Studia Papyrologica II”, Eos 32, 1929, 27-42.

E. Mignogna, "Narrativa greca e mimo: il romanzo di Achille Tazio", Studi italiani di filologia classica $89\left(1996=3^{\text {rd }}\right.$ series, 14), 232-242.

E. Mignogna, "Il mimo «Leucippe». Un' ipotesi su PBerol inv. 13927 [Pack² 2437]", Rivista di cultura classica e medioevale 38, 1996, 232-242.

S. Muth, Erleben von Raum - Leben im Raum, Zur Funktion mythologischer Mosaikbilder in der römisch-kaiserzeitlichen Wobnarchitektur (1998).

M. Önal, Mosaics of Zeugma (2003).

M. Önal, “Baraj Sonrası Zeugma'da Yapılan Kazı Çalışmaları”, in: R. Ergeç, (ed.), International Symposium of Zeugma: from past to future (2006) 135-148.

M. Önal, "Die Mosaiken im Triclinium des «Kointos-Hauses» in Zeugma", AMS 60, 2008, 263-273.

E. Pack, “Antiochia: Schema di uno spazio letterario semivuoto", in: G. Cambiano - L. Canfora - D. Lanza (edd.), Lo spazio letterario della Grecia antica, I. La produzione e 
la circolazione del testo. 2. L'ellenismo (1993) 717-767.

Panciera 1991

S. Panciera, "Struttura dei supplementi e segni diacritici dieci anni dopo", Supplementa Italica, n. s. 8 (1991) 9-21.

Parlasca 1989 K. Parlasca, “Das Mosaik von Mas'udije aus dem Jahren 228/29 n. Chr.”, DaM 1, 1989, 263-267.

Quet 1992

M.-H. Quet, "Romans grecs, mosaïques romaines", in: M.-F. Baslez - Ph. Hoffmann - M. Trédé, Le monde du roman grec (1992) 125-159.

Roscher 1916-24

W. H. Roscher, Ausführliches Lexikon der griechischen und römischen Mythologie (Band V), (1916-1924).

Rupprecht -

Hengstl 2006

H.-A. Rupprecht - J. Hengstl, Sammelbuch griechischer Urkunden aus Ägypten, Sechsundzwanzigster Band (Nr. 16341-16831), (2006).

Seeberg 2002-03

A. Seeberg, "Tragedy and archaeology, forty years after”, BICS 46, 2002-03, 43-75.

Waywell 1979

S. E. Waywell, "Roman Mosaics in Greece", AJA 83, 1979, 293-321.

Webster 1995

T. B. L. Webster, Monuments Illustrating New Comedy (3rd ed. revised \& enlarged by J. R. Green and A. Seeberg), Bulletin Supplement 50 (1995).

Wiemken 1972 H. Wiemken, Der griechische Mimus. Dokumente zur Geschichte des antiken Volkstheaters (1972). 
Some Observations on the Theonoe Mosaic from Zeugma

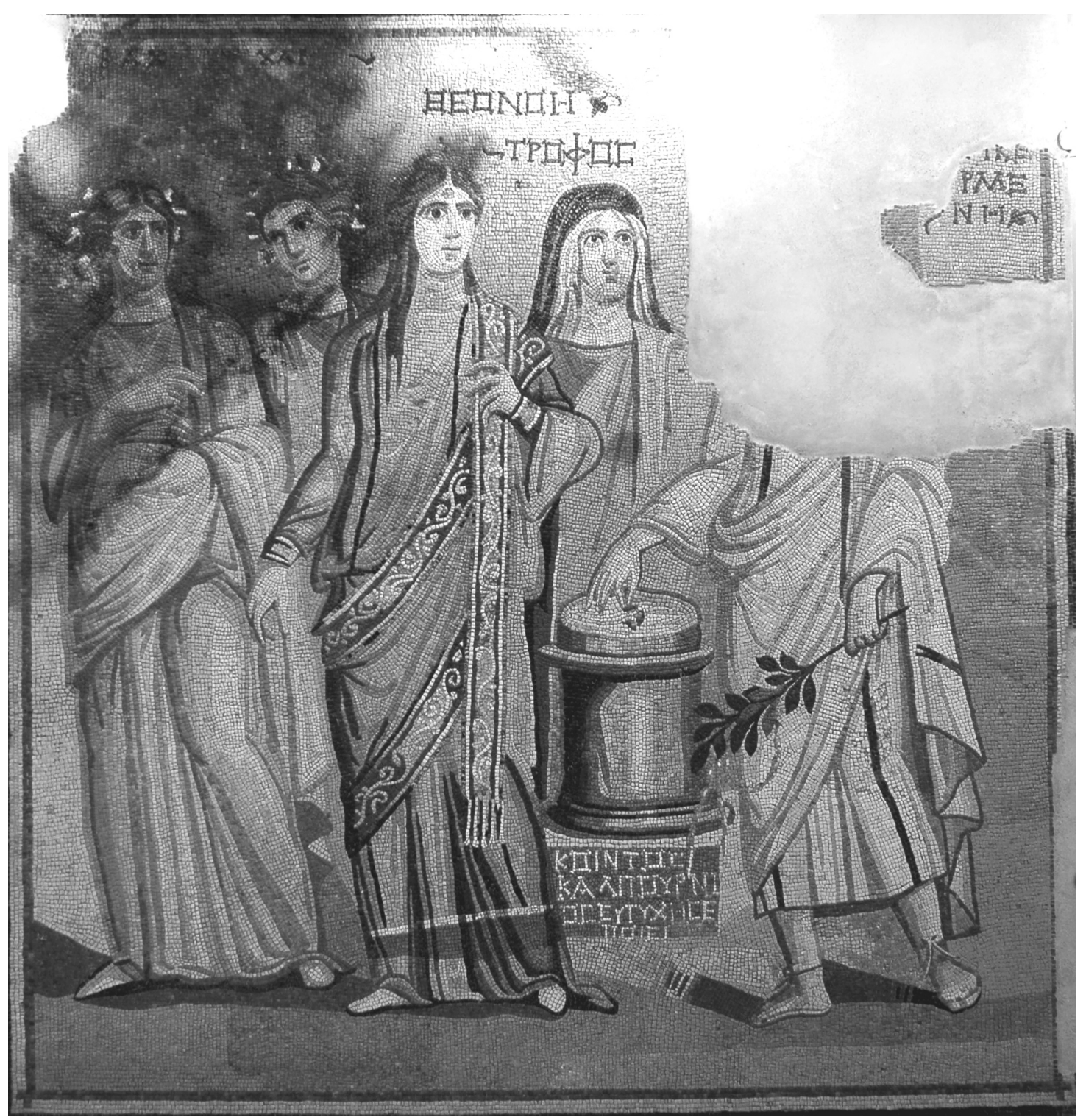

Figure 1

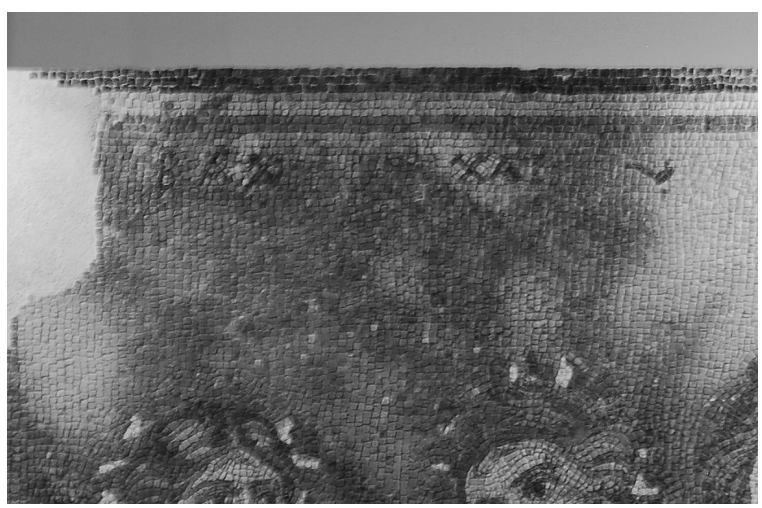

Figure 2

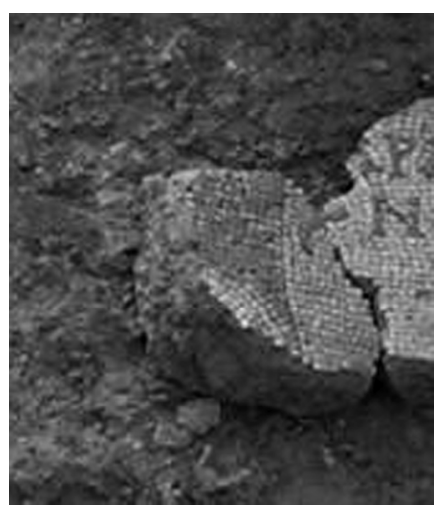

Figure 3 


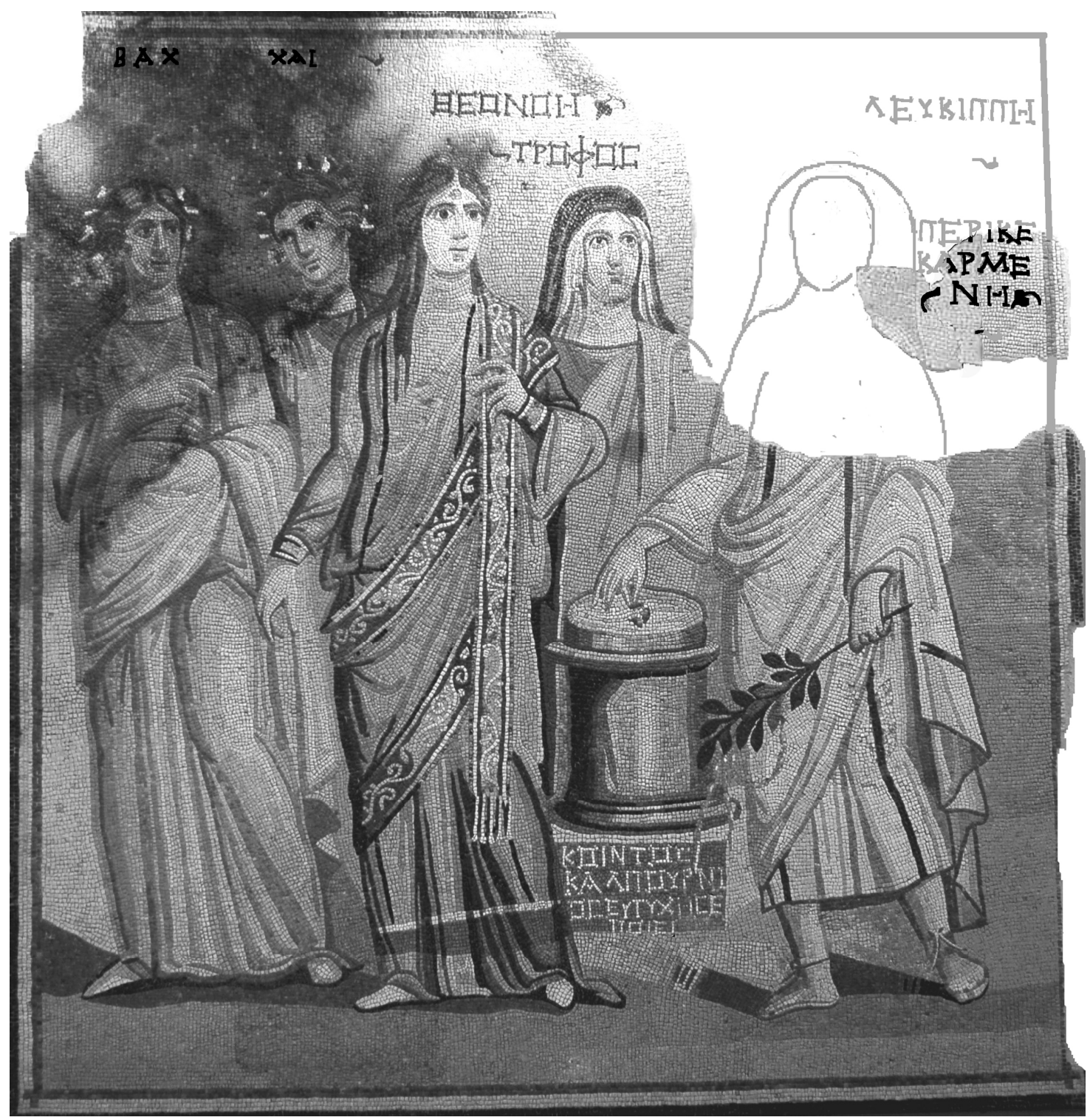

Figure 4 